\title{
Further delineation of the Yunis-Varon syndrome
}

\author{
RAOUL C M HENNEKAM* AND CHRISTINA VERMEULEN-MEINERS † \\ ${ }^{*}$ Clinical Genetics Center Utrecht, and +Sint Elisabeth Ziekenhuis, Amersfoort, The Netherlands.
}

SUMMARY A boy with intrauterine growth retardation, microcephaly, dysostosis of the skull, hypoplastic facial bones, labiogingival retraction, agenesis of the clavicles, distal aphalangia, and severely hypoplastic thumbs and halluces is described. The features are consistent with the Yunis-Varon syndrome. Review of published reports shows this to be a generalised disorder with variable manifestations in the skeletal, ectodermal, and cardiovascular systems. The consanguinity of the parents of the present case is in agreement with autosomal recessive inheritance.

In 1980, Yunis and Varon ${ }^{1}$ described five patients with cleidocranial dysostosis, severe micrognathia, bilateral absence of thumbs and first metatarsal bones, and distal aphalangia. They suggested that this was a newly recognised syndrome. Hughes and Partington ${ }^{2}$ described a similar patient in 1983 and proposed the name Yunis-Varon syndrome. A seventh patient was recently seen in Australia (M W Partington, 1987, personal communication). To the best of our knowledge, no other cases have been published since. Here we report another male patient in order to delineate the syndrome further. The consanguinity of the parents of the present case points to a probable autosomal recessive mode of inheritance. The dysmorphic features of the mother could be explained as expressions of the gene in the heterozygote.

\section{Case report}

The patient was the second born child of healthy, consanguineous parents of Dutch descent (fig 1). Their first born child was healthy. Both parents were 29 years old at the birth of the proband. A brother of the father was known to have ataxia telangiectasia. The mother noticed few fetal movements during the pregnancy which was otherwise normal. After $371 / 2$ weeks, delivery started spontaneously at home. After rupture of the membranes the umbilical cord bulged out, prompting urgent referral to hospital. On arrival, a stillborn boy was

Received for publication 15 December 1987.

Revised version accepted for publication 8 March 1988.

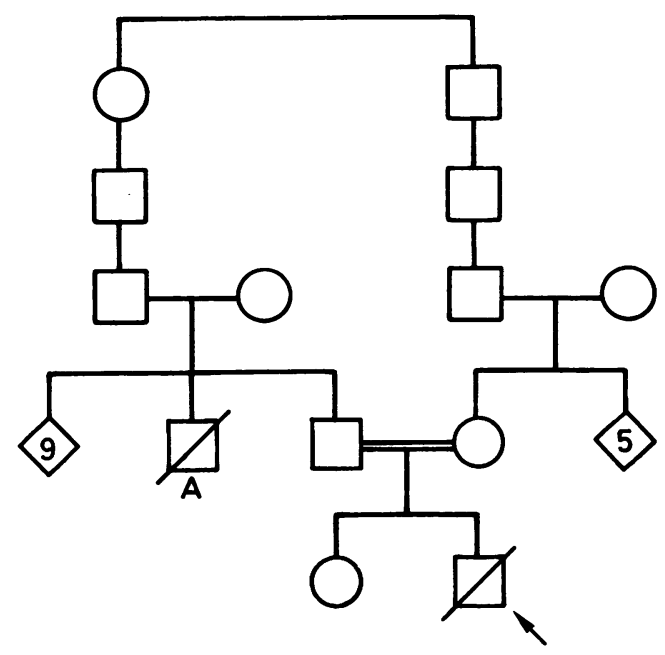

FIG 1 Family pedigree. Arrow points to proband. $A=$ patient with ataxia telangiectasia.

delivered who had multiple congenital anomalies (fig 2). Weight was $2350 \mathrm{~g}$ (3rd centile), length was $45 \mathrm{~cm}$ (3rd centile), and OFC was $30 \mathrm{~cm}(<3 \mathrm{rd}$ centile). His skull was soft with wide fontanelles and sutures, sparse scalp hair, and no eyebrows or eyelashes. The brain weighed $240 \mathrm{~g}$ (normal $340 \mathrm{~g}$ ) and had a normal macroscopic and microscopic appearance. He had small eyes, but the shallow orbital fossae resulted in some protrusion of the eyeballs. He had mongoloid palpebral fissures, anteverted nostrils, short upper lip, labiogingival retraction, and severe micrognathia with moderate glossoptosis. The palate was closed. The ears were low set, posteriorly rotated, and dysplastic. He had loose skin around the neck, absent clavicles, and absent nipples. Section of the internal organs showed no anomalies. There was hypospadias with descended testes. There was also nearly total agenesis of the thumbs, with short, pointed fingers showing little or no nail formation. He had rocker bottom feet, minimally formed, nailless halluces, pointed toes, and agenesis of the nails of the third, fourth, and fifth toes.

Laboratory investigations included screening for congenital infections (TORCH, syphilis, Listeria) with normal results. Chromosomal analysis of lymphocytes and fibroblasts gave a normal karyotype, 


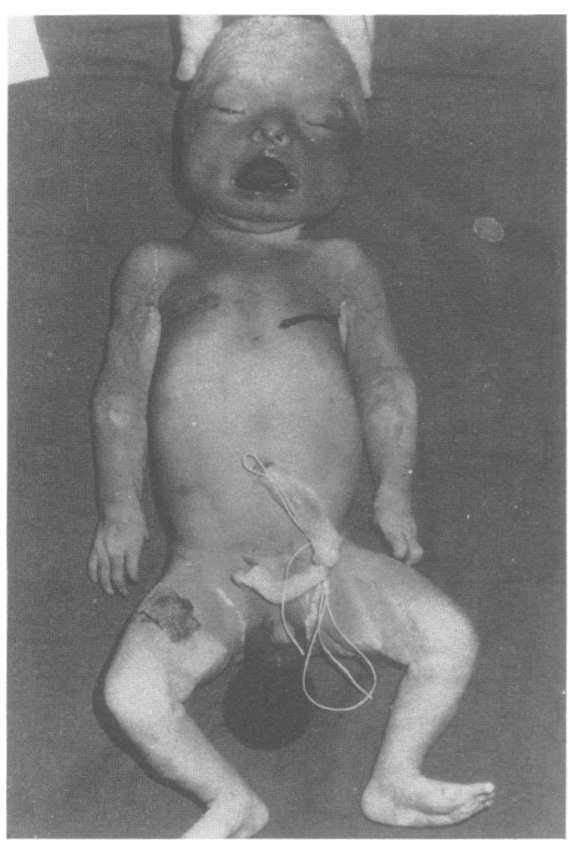

2 Presentpatient (postmortemphotographs). Notesparsehair craniofacial disproportion, labiogingival retraction, micrognathia, dysplastic and low set ears, hypospadias, absent thumbs and halluces, and short pointed fingers.

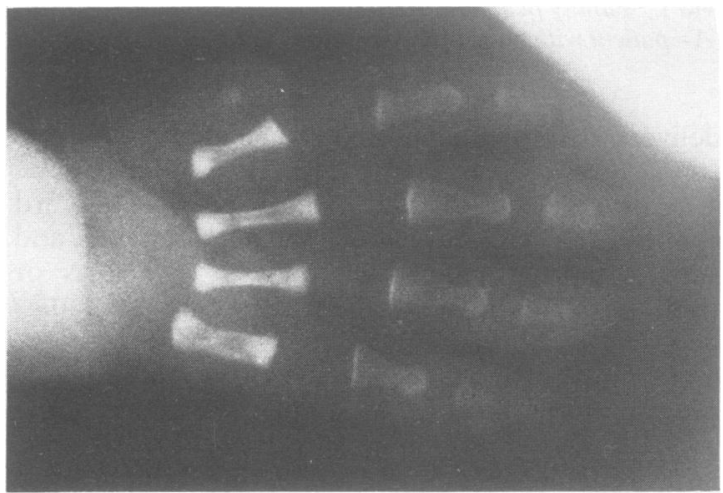

FIG $3 X$ ray of right hand. Note nearly complete absence of first ray and distal aphalangia of fingers.

$46, X Y$. No increased frequency of chromosome breaks or premature centromere separation was found.

Radiological investigations showed delayed ossification of calvarial bones, marked thickening of the nasal septum, hypoplastic facial bones, bilateral agenesis of the clavicles, no sternal ossification, slender ribs and long bones, almost complete bilateral absence of ossified bones of the first rays and absence of the distal phalanges of all other fingers (fig 3 ). $X$ rays of the pelvis showed hypoplasia of the iliac bones and probable bilateral hip

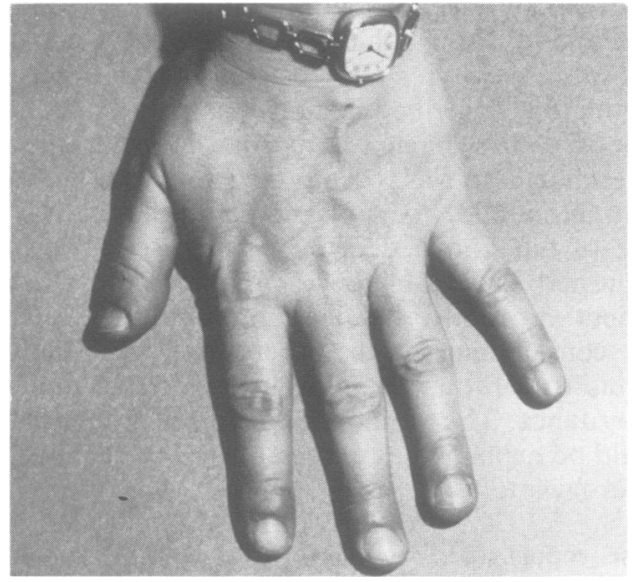

FIG 4 Right hand of proband's mother. Note short distal phalanges, especially of the thumb.

dislocation. The feet had no first metatarsal bones and hypoplastic proximal and distal phalanges of the big toes.

Physical examination of the mother showed slightly asymmetrical face, bilateral shortened thumbs, especially of the distal phalanges, and mildly shortened distal phalanges of all fingers (fi 4). The toes were normally formed. Radiologically ${ }_{\sigma}$ the distal phalanges of all digits were shortened. The 
TABLE SUmmary of clinical and radiological findings of all reported cases.

\begin{tabular}{|c|c|c|c|c|c|c|c|c|c|}
\hline Case & \multicolumn{5}{|c|}{$\begin{array}{l}\text { Yunis and } \\
\text { Varon' }{ }^{\prime}\end{array}$} & $\begin{array}{l}\begin{array}{l}\text { Hughes and } \\
\text { Partington }^{2}\end{array} \\
6\end{array}$ & $\begin{array}{l}\text { Partington }^{3} \\
7\end{array}$ & $\begin{array}{l}\begin{array}{l}\text { Present } \\
\text { patient }\end{array} \\
8\end{array}$ & Total \\
\hline $\begin{array}{l}\text { Sex } \\
\text { Birth length ( } \leqslant 3 \text { rd centile) }\end{array}$ & $\mathrm{F}$ & $\mathbf{M}$ & $\mathbf{F}$ & $\mathbf{F}$ & $\mathbf{F}$ & $\mathbf{M}$ & $\mathbf{M}$ & $\mathbf{M}$ & $4 \mathrm{~F} / 4 \mathrm{M}$ \\
\hline $\begin{array}{l}\text { Birth length }(\leqslant 3 \text { rd centile }) \\
\text { Birth weight }(\leqslant 3 \text { rd centile })\end{array}$ & - & + & + & + & + & + & & + & $6 / 7$ \\
\hline $\begin{array}{l}\text { Birth weight ( } \leqslant 3 \text { rd centile) } \\
\text { Microcephaly }\end{array}$ & - & + & + & + & + & + & - & + & $6 / 8$ \\
\hline $\begin{array}{l}\text { Microcephaly } \\
\text { Wide sutures/fontanelles }\end{array}$ & - & - & - & & & + & - & + & $2 / 6$ \\
\hline $\begin{array}{l}\text { Wide sutures/fontanelles } \\
\text { Sparse scalp hair }\end{array}$ & + & + & + & + & + & + & + & + & $8 / 8$ \\
\hline $\begin{array}{l}\text { Sparse scalp hair } \\
\text { Hypoplastic facial bones }\end{array}$ & + & + & + & + & + & + & + & + & $8 / 8$ \\
\hline Hypoplastic facial bones & + & + & + & + & & + & + & + & $7 / 7$ \\
\hline Small eyes & + & & + & & & - & - & + & $3 / 5$ \\
\hline Proptosis & & & & + & + & - & - & + & $3 / 5$ \\
\hline Anteverted nostrils & + & + & + & + & + & - & & + & $6 / 7$ \\
\hline Short upper lip & + & + & + & + & + & + & + & + & $8 / 8$ \\
\hline Labiogingival retraction & + & & + & & & + & + & + & $5 / 5$ \\
\hline Glossoptosis & + & & & & & - & - & + & $2 / 4$ \\
\hline Narrow/high arched palate & + & + & + & + & & + & + & - & $6 / 7$ \\
\hline Micrognathia & + & + & + & + & + & + & + & + & $8 / 8$ \\
\hline Low set/dysplastic ears & + & + & + & + & + & + & + & + & $8 / 8$ \\
\hline Loose skin in neck & & & & & & + & & + & $2 / 2$ \\
\hline Absent nipples & + & - & - & - & - & - & - & + & $2 / 8$ \\
\hline External genital anomalies & $\mathbf{N}$ & $\mathbf{M}$ & $\mathbf{N}$ & & & $\mathbf{N}$ & & $\mathrm{Hp}$ & $2 / 5$ \\
\hline Bilateral hip dislocation & + & + & + & & & - & - & + & $4 / 6$ \\
\hline Bilateral simian crease & + & + & & & & - & - & - & $2 / 5$ \\
\hline Absent thumbs & + & + & + & + & + & $\mathbf{H}$ & & + & $7 / 7$ \\
\hline Short, pointed fingers & + & + & + & + & + & + & & + & $7 / 7$ \\
\hline Nail hypoplasia/agenesis & + & + & + & + & + & - & - & + & $6 / 8$ \\
\hline Absent halluces & + & + & + & + & + & $\mathbf{H}$ & $\mathrm{H}$ & + & $8 / 8$ \\
\hline Short, pointed toes & + & + & + & + & + & $\mathbf{S}$ & $\mathbf{S}$ & + & $6 / 8$ \\
\hline Death in neonatal period & + & + & + & + & + & A & A & + & $6 / 8$ \\
\hline Calvarial dysostosis & + & & + & & + & + & & + & $5 / 5$ \\
\hline Wide sutures & + & & + & & + & + & & + & $5 / 5$ \\
\hline Craniofacial disproportion & + & & + & & + & + & & + & $5 / 5$ \\
\hline Micrognathia & + & & + & & + & + & + & + & $6 / 6$ \\
\hline Absent clavicles & + & & $\begin{array}{l}\mathrm{LH} \\
\mathrm{R}+\end{array}$ & & + & $\begin{array}{l}\text { LN } \\
\text { RH }\end{array}$ & $\mathbf{H}$ & + & $6 / 6$ \\
\hline Absent sternal ossification & + & & + & & + & & & + & $4 / 4$ \\
\hline Pelvic dysplasia (B) & + & & + & & & & & + & $3 / 3$ \\
\hline Hip dislocation & + & & + & & & & - & + & $3 / 4$ \\
\hline Agenesis of thumbs & + & & + & & + & $\mathbf{H}$ & & + & $5 / 5$ \\
\hline $\begin{array}{l}\text { Agenesis of distal phalanges } \\
\text { of fingers }\end{array}$ & + & & + & & + & - & & + & $4 / 5$ \\
\hline Agenesis of middle phalanges & & & & & & & & & \\
\hline of fingers & 2nd & & 2nd & & 2nd & 2nd. 5th & & - & $4 / 5$ \\
\hline Agenesis of 1st metatarsals & + & & + & & + & $\mathbf{H}$ & - & + & $5 / 6$ \\
\hline $\begin{array}{l}\text { Hypoplasia of hallucal } \\
\text { phalanges }\end{array}$ & + & & + & & + & + & & + & $5 / 5$ \\
\hline $\begin{array}{l}\text { Agenesis of distal phalanges } \\
\text { of toes }\end{array}$ & & & & & & + & $\mathbf{H}$ & $\mathbf{H}$ & $3 / 3$ \\
\hline
\end{tabular}

$M=$ micropenis, ectopic testes. $\mathrm{Hp}=$ hypospadias. $\mathrm{N}=$ normal. $\mathrm{H}=$ hypoplasia. $\mathrm{S}=$ syndactyly of 2 nd to 4 th toes bilaterally. $\mathrm{A}=$ alive at nine years (case 6 ) and three years (case 7). $\mathrm{B}=$ flattened acetabuli, decreased iliac diameter. $\mathrm{L}=$ left. $\mathrm{R}=$ right.

skull and clavicles were normally formed. Physical and radiological examination of the father showed no anomalies.

\section{Discussion}

The clinical and radiological features of the present patient are compared with previously reported patients in the table. The main characteristics of the Yunis-Varon syndrome are prenatal and postnatal growth deficiency, craniofacial disproportion, agenesis or hypoplasia of the clavicles, digital anomalies, especially extreme hypoplasia of the first rays, and usually a lethal course in the neonatal period.

The hypoplastic facial bones can give the impression of macrocrania, although two patients were in fact microcephalic, and cause shallow orbital fossae with moderate exophthalmia and anterior placement of the temporomandibular joint. Together with the micrognathia it can also cause glossoptosis. The labiogingival retraction can give rise to the diminished nasolabial distance and 'thin lips'. ${ }^{1}$

The severity of the digital anomalies varies; most patients had complete or nearly complete agenesis of the thumbs and big toes. All other fingers and 
toes can show hypoplasia or agenesis of the distal phalanges. The patients described by Hughes and Partington $^{2}$ and Partington ${ }^{3}$ had less severe digital anomalies. These patients had, in addition, soft tissue syndactyly of the fingers and toes. All patients had deficient scalp hair and nearly all had nail hypoplasia or agenesis. Other ectodermal anomalies are found in tooth and nipple formation. The patients that died in the neonatal period are not known to have had skin anomalies. The patient of Partington ${ }^{3}$ had a dry skin with episodic peeling over the fingers. This patient also had a cardiomyopathy, which caused an irregular heart rhythm in utero. One of the surviving patients is severely retarded, but the other seems to have normal intellectual development at the age of three years. ${ }^{3}$

The differential diagnosis includes cleidocranial dysostosis, ${ }^{4}$ but there is also some overlap with Roberts' syndrome. ${ }^{5}$ A more extensive review of anomalies associated with clavicular hypoplasia or agenesis can be found elsewhere. ${ }^{6}$ The presence of the syndrome with equal severity in sibs of both sexes, the similarity of symptoms in all cases, the absence of reports of the syndrome in more than one generation, and the consanguinity in three of the six families described point to an autosomal recessive mode of inheritance. The finding of shortening of the thumbs and distal phalanges in the mother of the present patient could be interpreted as an expression of the gene in the heterozygote. No such anomalies were found in the parents of the other patients, but radiological investigations were nof performed, so it remains uncertain whether these anomalies could occur more often.

We wish to thank Professor M W Partington $\frac{\overline{\bar{D}}}{\overline{\mathrm{D}}}$ (Ontario, Canada) and Dr H E Hughes (Cardiff) for additional information on their patients, F A M Hennekam for pedigree analysis, and F J Van Waeries for excellent technical assistance.

\section{References}

1 Yunis E, Varon $\mathrm{H}$. Cleidocranial dysostosis, severe micrognath ism, bilateral absence of thumbs and first metatarsal bones, ant distal aphalangia. Am J Dis Child 1980;134:649-53. N

2 Hughes HE, Partington MW. Brief clinical report: the syndrome of Yunis and Varon-report of a further case. Am J Med Genet 1983;14:539-44.

3 Partington MW. Cardiomyopathy added to the Yunis-Varon syndrome. Proc Greenwood Genetic Center 1988;7:224-5.

4 Jarvis JL, Keats TE. Cleidocranial dysostosis: a review of $4 \vec{Q}$ new cases. AJR 1974;121:5-16.

5 Parry DM, Mulvihill JJ, Tsai S, Kaiser-Kupfer MI, Cowan JM $\stackrel{\text { 己 }}{2}$ SC phocomelia syndrome, premature centromere separation and congenital cranial nerve paralysis in two sisters, one witk malignant melanoma. Am J Med Genet 1986;24:653-72.

${ }^{6}$ Hall BD. Syndromes and situations associated with congenitabo clavicular hypoplasia or agenesis. In: Papadatos CJ, Bartsocas CS, eds. Skeletal dysplasias. New York: Alan R Liss, 1982D $279-88$.

Correspondence and requests for reprints to $D \stackrel{\overline{2}}{2}$ R C M Hennekam, Clinical Genetics Centrę Utrecht, Postbox 18009, 3501 CA Utrecht, The Netherlands.

\title{
A case of interstitial deletion of $10 \mathrm{q} 25.2 \rightarrow \mathrm{q} 26.1$
}

\author{
D E ROONEY*, K WILliams*, D V COLEMAN*, AND A HABEL $\dagger$ \\ ${ }^{*}$ Cytogenetics Unit, St Mary's Hospital, London; and †Department of Paediatrics, West Middlesex Universit ${ }_{3}$. \\ Hospital, London.
}

SUMMARY A de novo interstitial deletion of chromosome 10, del(10)(pter $\rightarrow$ q25.2::q26.1 $\rightarrow$ qter), was detected in a newborn female with facial anomalies, failure to thrive, and subsequent developmental delay. This case is compared with 10 previous reports of monosomy $10 \mathrm{q}$ within the $\mathrm{q} 25 \rightarrow \mathrm{qter}$ region.

\section{Case report}

The proband (fig 1) was the first child of unrelated parents, both in their twenties and from large families with no history of congenital malformation. The pregnancy was uneventful except for a varicella

Received for publication 8 December 1987.

Revised version accepted for publication 25 March 1988 infection at six weeks, and labour was induced five days after term producing a liveborn, $2960 \mathrm{~g}$ female $\frac{D}{0}$ Respiratory effort was poor with Apgar scores of 3 . at one minute, 6 at five minutes, and 9 at 105 minutes. There was some meconium staining of the liquor.

The baby was noted to be of unusual appearance, microcephalic, and brachycephalic. She also has poor muscle tone. Facial features included hypero telorism, prominent, broad nasal bridge, thin, bow shaped upper lip, long philtrum, long, narrow face $;$ and poorly developed jaw angles. The only other abnormal finding was bilateral, flat, hypoplastiç् labia majora. The baby failed to thrive for 10 days? after birth.

Later review at six months of age showed tha代 